\title{
Evaluating Clinical Pathway Typhoid Fever Monitoring at ABC Hospital Malang
}

\author{
Ika Shanti Rosalina*, Muhammad Mansur, M. Kuntadi Syamsul Hidayat, Kurnia Widyaningrum \\ *Correspondent Author: ika.rosalina@yahoo.com \\ *PPS MMRS, Faculty of Medical in Universitas Brawijaya, Indonesia
}

\begin{tabular}{l}
\hline I N D E X I N G \\
\hline Keywords: \\
Clinical Pathway; \\
Typhoid Fever; \\
Monitoring
\end{tabular}

\begin{abstract}
A B S T R A C T
ABC Hospital has implemented 15 Clinical Pathway, and Typhoid Fever is the most cases that can be served. The inaccuracy of the monitoring report on the implementation of Clinical Pathway has prevented the hospital from taking appropriate actions to improve the implementation of Clinical Pathway Typhoid Fever. This study aims to determine the obstacles of monitoring implementation of Clinical Pathway Typhoid Fever in ABC Hospital. This research is a case study and descriptiveexplorative research, using document review, field observation, interview, and questionnaire for data collection. The research was conducted in the in-patient wards and medical records room of $\mathrm{ABC}$ Hospital during September 2017. The respondents of the research include room physicians, head of inpatient rooms, pediatric, internist, pharmacist, nutritionist, and medical record staff. The result show that factors which impeded implementation of Clinical Pathway monitoring in $\mathrm{ABC}$ Hospital were the absence of Clinical Pathway team, the incompatibility of the Clinical Pathway Guide content, the absence of SOP of Clinical Pathway filling form, and the lack of socialization. Suggestion for improving monitoring of Clinical Pathway Typhoid Fever are establish a Clinical Pathway team, revise the Guidance of Clinical Pathway, compile SOP of Clinical Pathway filling form, and do socialization.
\end{abstract}

Kata Kunci:

Clinical Pathaway;

Typhoid Fever;

Monitoring

\begin{abstract}
RS ABC telah menerapkan 15 Clinical Pathway, dan Typhoid Fever merupakan kasus terbanyak yang dapat dilayani. Ketidakakuratan laporan monitoring pelaksanaan Clinical Pathway menyebabkan rumah sakit tidak dapat mengambil langkah perbaikan pelaksanaan Clinical Pathway Typhoid Fever dengan tepat. Penelitian ini bertujuan untuk mengetahui kendala pelaksanaan monitoring Clinical Pathway Typhoid Fever di RS ABC. Penelitian ini merupakan studi kasus yang dilakukan di ruang rawat inap dan rekam medis RS ABC selama September 2017. Data dikumpulkan melalui pendekatan deskriptif-eksploratif dengan melakukan telaah dokumen, observasi lapangan, wawancara, dan kuesioner. Responden meliputi dokter ruangan, kepala ruang rawat inap, profesional pemberi asuhan, perawat, dan staf rekam medis. Hasil penelitian menunjukkan bahwa faktor-faktor yang menjadi kendala pelaksanaan monitoring Clinical Pathway di RS ABC adalah belum terbentuknya tim Clinical Pathway, ketidaksesuaian isi Panduan Clinical Pathway, belum adanya SPO pengisian form Clinical Pathway, dan kurangnya sosialisasi. Untuk mengatasi kendala tersebut, saran yang diberikan adalah menbentuk tim Clinical Pathway, merevisi Panduan Clinical Pathway, menyusun SPO pengisisan form Clinical Pathway, dan melakukan sosialisasi.
\end{abstract}

(C) 2018 JMMR. All rights reserved

Article history: Received 2018-Apr-10 ; Revised 2018-Apr-11; Accepted 2018-May-04

\section{INTRODUCTION}

The era of national health insurance or better known as JKN (Jaminan Kesehatan Nasional) and high levels of competition among hospitals have changed the management paradigm of the hospital to focus more on the customer. Hospitals should pay attention to the quality of service and customer satisfaction including conducting good clinical governance. Hospital should pay attention to cost efficiency in improving service quality. The most effective method to improve the service quality to patients without increasing cost is by reducing the variation of service. To meet this need, clinical pathway is a device commonly used to prevent the occurrence of unnecessary service variations. ${ }^{1,2}$ Clinical Pathway is applied for high volume, high risk, and high cost medical cases. ${ }^{3}$

Clinical Pathway is defined as an integratedscheduled health intervention plan within a certain time limit and requires collaboration among care givers. ${ }^{4,5}$ Clinical Pathway can be useful as a guide to decision making in performing patient service. ${ }^{5}$ Clinical Pathway is prepared on the basis of Evidence Based Medicine (EBM) 
guidelines, good practices, and patient expectations. Clinical pathways provide an overview of the service flow received by a patient from coming and being treated to getting out of the hospital. ${ }^{4,6}$ The Clinical Pathway aimed to improve the quality of service, reduce risk, enhance patient satisfaction, and increase the efficiency of the use of resources power in doing service to patient. ${ }^{3,6,9-12}$ Through the implementation of Clinical Pathway, it is expected that the quality of service can be increased with affordable and estimated cost. ${ }^{5}$

Implementation of Clinical Pathway for inpatient's service should consider that all patent service activities are conducted in an intregated, patient-oriented, and sustainable manner. Implementation of Clinical Pathway also involves all health professions such as doctors, nurses, midwives, laboratories, pharmacists, nutritionists, physiotherapists, and other care giver. Clinical Pathways are applied in certain cases within the prescribed time and recorded in the form of daily periods. Clinical Pathway is recorded as documentation of all service activities, and any deviattion step is recorded as a variance. ${ }^{5}$

The Clinical Pathway will function effectively as a quality control and cost control device unless the organization regularly monitors and evaluates the implementation of the Clinical Pathway. ${ }^{13}$ The Clinical Pathway evaluation includes implementation of Clinical Pathway, variance in Clinical Pathway implementation, and staff satisfaction. Hospital should analyze whether Clinical Pathway is applied to appropriate cases and whether any information is missing from Clinical Pathway. ${ }^{1}$ Variance analysis in Clinical Pathway including the presence of variance, variance recording, and staff's understanding of variance. Variance occuring in the implementation of Clinical Pathway may be caused by a disease's natural condition, presence of comorbidities, presence of complications, or medical errors. ${ }^{5}$ Variance analysis needs to be done wisely to distinguish a noncompliance behavior toward the Clinical Pathway or the contents of the Clinical Pathway have been incompatible with current science and require revision. ${ }^{13}$ Staff satisfaction on Clinical Pathway can affect the degree of compliance of Clinical Pathway implementation. Staff satisfaction related to Clinical Pathway can be evaluated through questionnaire. ${ }^{1}$ Obstacles in analyzing variance include the definition or criteria of variance not yet clearly defined, difficulty in collecting and analyzing variance, and no reporting of clinical pathway. ${ }^{14}$ The accurate results from evaluating the implementation of Clinical Pathway will cause the hospital to be able to determine appropriate follow-up.

$\mathrm{ABC}$ hospital is a private hospital situated in Malang which has been accredited and cooperated with the Healthcare and Social Security Agency or generally known as BPJS Kesehatan. Based on ABC hospital medical records data in July 2017, most of ABC hospital's inpatients were BPJS Kesehatan (80.27\%) followed by non insurance patient $(18,64 \%)$, and other insurance $(1,09 \%)$. This condition caused $\mathrm{ABC}$ hospital has to make efforts to control cost by implementing Clinical Pathway. Clinical Pathway began to be implemented since 2015 in stages. ABC Hospital has 15 Clinical Pathways, are Acute Appendicitis, Typhoid Fever, Dengue Fever, Acute Gastroenteritis, Congestive Heart Failure, Febrile Seizures, Non ST Elevation Myocard Infarct, Thrombotic CVA, Bronchopneumonia, Bronchitis, Penumonia, Asthma, COPD, and Tuberculose. Among 15 Clincal Pathways, Typhoid Fever was the highest inpatient case and the highest Clinical Pathway case.

In the report of Clinical Patway, the number of Clinical Pathway non-compliance for the period of January - June 2017 was 30.94\%, with the biggest cause being noncompliance with long days of care. The preliminary study was done by reviewing the Clinical Pathway Typhoid Fever report from May to June 2017 to know the accuracy of Clinical Pathway reporting. The re-examination was conducted by taking a sample of $50 \%$ of Typhoid Fever patients who experienced medical care which was not appropriate with Clinical Pathway during May to June 2017. Clinical Pathway Typhoid Fever is chosen considering Typhoid Fever is the highest inpatient and Clinical Pathway case.

In addition, 23 samples medical record document of Typhoid Fever patient were collected to re-examine Clinical Pathway incompatibility. The results of reexamination showed only 6 patients (26.09\%) were suffered from Typhoid Fever as the final diagnosis. There were eleven patients $(47.83 \%)$ diagnosed with Typhoid Fever accompanied by (dengue fever, urinary tract infections, cystitis, bronchopneumonia, and anemia), even six people (26.09\%) were not finally diagnosed as Typhoid Fever, but Bronkopneumonia, Acute Glomerulonephritis + Nefrotik Syndrome, GERD dd CHF, Hypertension + vertigo, Gastritis + Anemia + PVC, and Cholelithiasis. 
The results of a review of Clinical Pathway report data informed the incompatibility of Clinical Pathway hospital report data and the results of re-examination. The final diagnosis reported in the evaluation of the implementation of Clinical Pathway Typhoid Fever consisted of not only single diagnoses of Typhoid Fever but also with Typhoid Fever complication cases even nonTyphoid Fever cases. Hospital reports on the implementation of Clinical Pathway from May to June 2017 showed that Clinical Pathway mismatch occurred mainly in LOS (length of stay) that was $22.92 \%$. The report data was inconsistent with the results of re-examination of the six patients with one diagnosis of Typhoid Fever who $(100 \%)$ had a total length of stay in accordance with Clinical Pathway standard ( $\leq 4$ days). The inaccuracy of Clinical Pathway monitoring data will make the hospital unable to know the condition of the Clinical Pathway implementation as well as the follow-up that is taken become inaccurately targeted. This study aims to map the constraints that occur in monitoring the implementation of Clinical Pathway Typhoid Fever at ABC hospital.

\section{RESEARCH METHOD}

The present study employed a case study with descriptive explorative research design to explore and analyze the constraints that occur in the implementation of Clinical Pathway Typhoid Fever monitoring. The study was conducted during September 2017 at ABC hospital. The data collection were garnered from field observation, document review, interviews, and questionnaires.

Field observations were carried out by observing the data collection flow of Clinical Pathway implementation, the availability of Clinical Pathway Typhoid Fever form in the inpatient room, and the implementation of filling out form of Clinical Pathway Typhoid Fever in the inpatient room. The observation took place in the inpatient room and medical record installation of $\mathrm{ABC}$ hospital. Document review was conducted on the Clinical Pathway guide at $\mathrm{ABC}$ hospital. The interview aimed to find out the level of staff understanding about the data collection flow of Clinical Pathway implementation and Clinical Pathway monitoring procedure. Interviews were carried out to hospital staff directly involved in implementing and monitoring Clinical Pathway at ABC hospital, they were one room doctor as Clinical Pathway implementer, three heads of inpatient room, inpatient nurses, the head of Medical Record Installation, Medical Record analysis staff, as well as the Chairman of the Medical Committee.
Meanwhile, interview materials include staff knowledge of hospital policies on the implementation of Clinical Pathway, procurement of Clinical Pathway Typhoid Fever form in the inpatient room, who is responsible for filling the Clinical Pathway form, determining and recording variance, how is the Clinical Pathway form collection path, as well as who is responsible for managing or following up on the implementation of Clinical Pathway data. The questionnaires were used to reinforce the interview data with the same objectives and topics as the target and the topic of the interview.

Interviews and questionnaires were conducted in September 2017. Out of 30 questionnaires distributed, 27 questionnaires were filled by 1 room doctor, 3 heads of inpatient room, 3 caregivers involved in the implementation of Clinical Pathway, 3 medical recording personnels, and 17 nurses of inpatient room.

All primary and secondary data obtained through field observation, document review, interviews, and questionnaires were analyzed using a fishbone diagram to determine the root of the problem regarding the implementation of Clinical Pathway monitoring at $\mathrm{ABC}$ hospital.

\section{RESULT AND DISCUSSION}

\section{Policies and Hospital Management}

The support of hospital management on the implementation of the Clinical Pathway was shown through the establishment of the Clinical Pathway Guide. The Clinical Pathway guide of $\mathrm{ABC}$ hospital was prepared in 2015 and has never been reviewed. This guide sets out several issues related to the implementation of Clinical Pathway at $\mathrm{ABC}$ hospital such as the team who was responsible for the implementation of Clinical Pathway at ABC hospital was the Clinical Pathway Coordinator under the Medical Committee assisted by the Clinical Pathway coordinator of each specialization; Clinical Pathway monitoring was done by the Medical Committee, case manager (room physician and head of the inpatient room), as well as medical records; The recording and reporting of the Clinical Pathway implementation is carried out through a daily census conducted by the case manager and head of the room. The evaluation of recording and reporting results was done by the medical record; Clinical Pathway reporting flow at $\mathrm{ABC}$ hospital is Clinical Pathway form from emergency department or polyclinic, or inpatient ward submitted to medical record for analysis, the analysis result 
by medical record staff was then reported to Medical Committee for follow up.

Through interviews with doctors in charge of Clinical Pathway and the head of Medical Record Installation, it was known that the team/coordinator of Clinical Pathway has not been established yet and there was not any director's decree. Some of the materials in the Clinical Pathway Guidelines need to be revised because they were not appropriate with Clinical Pathway implementation standards such as the implementation of Clinical Pathway at the emergency departement or polyclinic, and Clinical Pathway analysis which was done by medical record staff. Some Clinical Pathway monitoring procedures were not clear such as determining diagnosis using Clinical Pathway: is it limited to a single diagnosis of Typhoid Fever or includes Typhoid Fever with other accompanied diseases. There was only one staff member who knows about the Clinical Pathway Guides. The room physician and the head of the inpatient ward are not aware of any Clinical Pathway guidance.

Inpatient and medical record staff also said that there was no SPO or other written rules could clarify the Clinical Pathway monitoring procedures including SPO about filling of the Clinical Pathway form in the room.

\section{Human Resources}

Data collection for monitoring the implementation of Clinical Pathway Typhoid Fever was done by one physician of the room, carried out along with the duty as a room doctor. The function of the head of the inpatient room as the case manager who was responsible for filling the Clinical Pathway form did not work.

Interviews with room physicians, heads of inpatient rooms, pharmacists and nutritionists led to a lack of supervision by hospital management of Clinical Pathway form filling in inpatient rooms, lack of socialization of staff, the perception that Clinical Pathway is only the doctor's authority, and Clinical Pathway is assessed as an additional workload as an obstacle to the implementation of Clinical Pathway monitoring. One of the three heads of inpatient stated that she did not know the Clinical Pathway at all including the Clinical Pathway Typhoid Fever form. Two head of inpatient rooms claimed that they ever know the Clinical Pathway Typhoid Fever form but they did not remember how to fill it. Socialization has been done limited to the head of the inpatient room before accreditation and has not been re-socialized despite the shift of head of the inpatient room.

The results of the questionnaire showed that $11.11 \%$ of respondents did not know that Typhoid Fever was one diagnosis that has Clinical Pathway at $\mathrm{ABC}$ hospital; $18,532 \%$ did not know the Clinical Pathway Typhoid Fever form; $33.33 \%$ of respondents said that Clinical Pathway was not just a doctor's job; only $33.33 \%$ of the respondents had received training on filling the Clinical Pathway form; and $81.48 \%$ of respondents stated that Clinical Pathway provided benefits in the management of Typhoid Fever patients without complications.

\section{Clinical Pathway Report and Evaluation Procedures}

Starting early September 2017, ABC hospital attempted to reactivate the Clinical Pathway form as a monitoring data collection tool for the implementation of Clinical Pathway. Field observations were made to observe the Clinical Pathway form filling process, as well as the flow of report and evaluation. The results of field observations include: there was no any Clinical Pathway form in the inpatient room including Clinical Pathway Typhoid Fever form; the Clinical Pathway form was not found in the medical records document of Typhoid Fever inpatients who returned to the medical record; the Clinical Pathway form filling activity was not found in inpatient wards; Since September 2017, the Clinical Pathway Typhoid Fever form has been distributed by medical record analysis officers to the medical record status of Typhoid Fever patients after KRS and submitted to the room physician for completion; and there is only one staff member (physician) who fills out the Clinical Pathway audit form and recaps the Clinical Pathway implementation data.

The results of the interview reinforce the results of field observations that the recording of the implementation of Clinical Pathway was done by one physician of the room together with the task of completing the medical record document. Recording was done in Clinical Pathway notebooks and not all patients can be listed due to time and energy constraints. Recording the implementation of Clinical Pathway was assisted by medical record staffs who have not received either training or socialization due to inactivity of the head of the inpatient room as the case manager responsible for filling the Clinical Pathway form. Medical record staff perform data collection by utilizing hospital information system to obtain inpatient data admitted with diagnosis of Typhoid Fever. The 
disadvantage of this method is the recorded diagnosis is an initial diagnosis (diagnosis when the patient is admitted). Hospital information system has not recorded the final diagnosis of the patient when out of hospital. The data will be submitted to the doctor room for recapitulation.

Beginning in September 2017, medical record staff did not conduct data withdrawal for monitoring of Clinical Pathway via Hospital information system. The medical record staff will set aside the medical records of inpatients with a Clinical Pathway diagnosis, complete the Clinical Pathway form, and submit to the room physician to fill out.

Besides performing the recording function, physician room also performed recapitulation and analysis of data implementation of Clinical Pathway. The results of the analysis were then reported to the head of Medical Installation and the chairman of Committee for Quality Improvement and Patient Safety for follow up. In fact, there has been no follow-up from the Medical Committee on the results of monitoring the implementation of Clinical Pathway at $\mathrm{ABC}$ hospital.

\section{Environment}

Involvement and communication among caregivers in monitoring the implementation of Clinical Pathway Typhoid Fever at $\mathrm{ABC}$ hospital still has not run well. Interviews with pediatricians, internist, pharmacists, nurses and nutritionists informed that the caregivers involved in the implementation of Clinical Pathway have not received feedback from monitoring and evaluation results of Clinical Pathway Typhoid Fever implementation. The caregivers' understanding regarding Clinical Pathway Typhoid Fever and monitoring procedures has not met. This condition was assessed by the physician as a factor causing the low commitment of the implementation of Clinical Pathway.

The data obtained through document review, field observation, interviews, and questionnaires were used to analyze the problem through fish bone diagrams as shown below: 


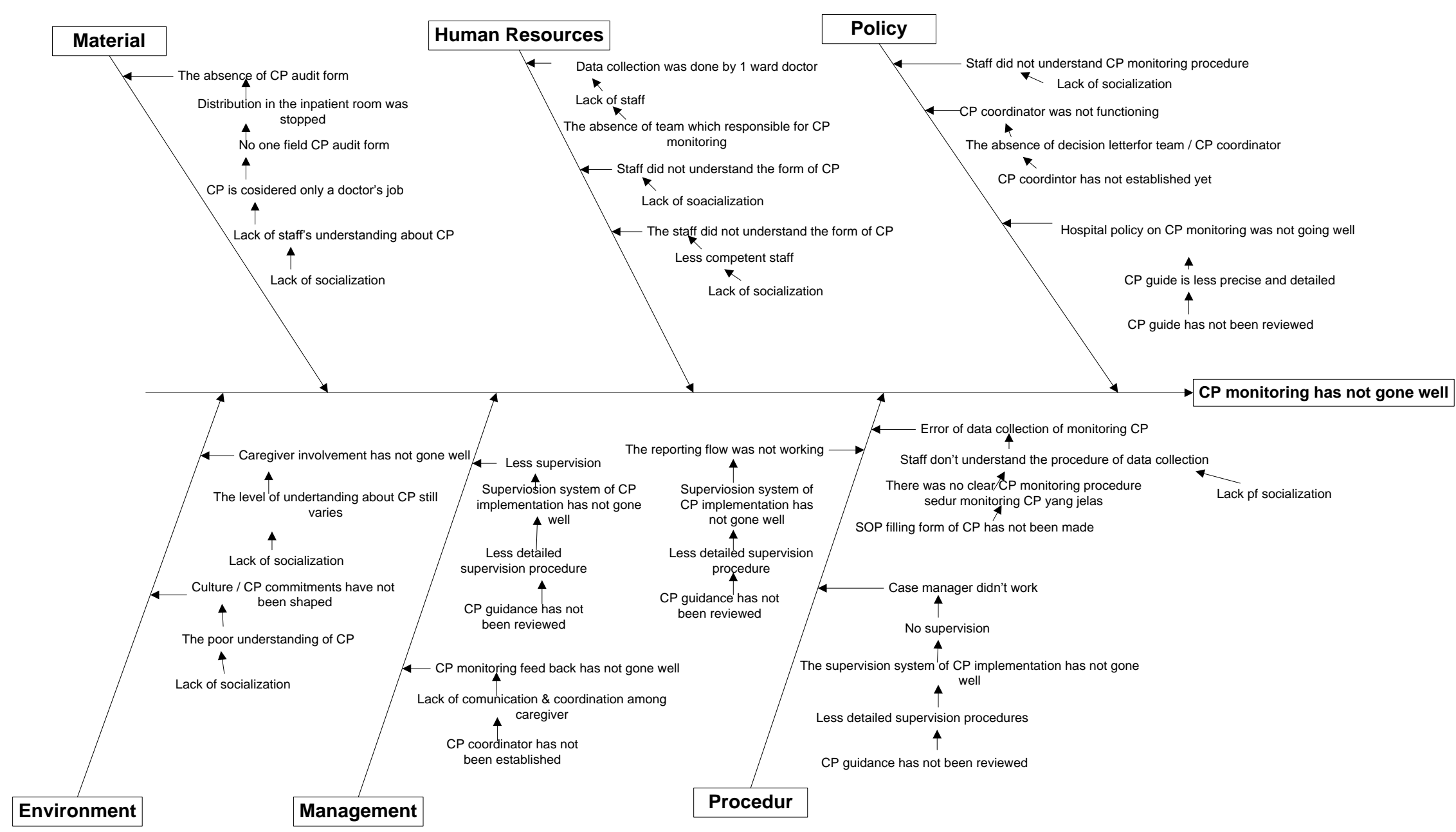

Figure 1. Fish bone of the root problem of Clinical Pathway monitoring 
In accordance with the Clinical Pathway of $\mathrm{ABC}$ hospital, the team who was responsible for the implementation of Clinical Pathway including its monitoring should be established immediately. Multidisciplinary teams are required in the preparation and implementation of Clinical Pathway. ${ }^{11,15-17}$ ABC Hospital requires a team responsible for the implementation of the Clinical Pathway. This team involves medical committee and other health professions. ${ }^{5,18}$ Monitoring and evaluation of the implementation of the Clinical Pathway can collaborate with the team of quality improvement and patient safety. ${ }^{19} \mathrm{ABC}$ Hospital may consider the composition of the Clinical Pathway team in accordance with the abilities and conditions of the hospital, but at least consist of chairmen, secretaries, and members. The team formed is authorized by the Director's Decision and the hospital needs to determine the duties and responsibilities of each.

$\mathrm{ABC}$ hospital has a Clinical Pathway Guidance as the basis or guidance of Clinical Pathway implementation but it has not socialized yet to the staff concerned. Lack of socialization as one of the obstacles in the implementation of Clinical Pathway at the hospital. ${ }^{20}$ Training of staff involved in the implementation of Clinical Pathway should be conducted intensively and thoroughly. Clinical Pathway socialization for ABC Hospital staff is needed to provide insight into the understanding, benefits, types of Clinical Pathway applicable at $\mathrm{ABC}$ Hospital, and procedures for Clinical Pathway monitoring. The trainees are medical staffs, nurses, pharmacists, nutritionists, and other staff involved in the implementation of the Clinical Pathway at ABC Hospital. Further training can be given to the case manager (room physician and head of the inpatient room) as the staff responsible for recording / filling the Clinical Pathway form in the inpatient ward. Clinical Pathway socialization should be sustainable. Further training can be undertaken for certain staff to emphasize the responsibility or coordination of the implementation of Clinical Pathway. ${ }^{21}$ Clinical Pathway socialization / training can be done routinely or incidentally. ABC Hospital may include Clinical Pathway material in routine in-house training schedule, at least once a year. Incidental training is undertaken if there is a change of staff in charge of the Clinical Pathway such as a room physician or head of the inpatient room. Initial socialization can be done after the revision of guidelines and preparation of Clinical Pathway SOP completed.
This condition was getting worse by the absence of SOP filling Clinical Pathway form in the implementing unit. Standard Operating Procedures (SOP) for Clincal Pathway form filling is required as a guideline for the case manager so that the filling of the Clincal Pathway Typhoid Fever form can be done uniformly. The SOP contains detailed steps / instructions on filling the Clinical Pathway Typhoid Fever form including the recording of variance. ${ }^{5}$

The Clinical Pathway Guide which was not socialized yet and the absence of SOP in the implementing unit was one of the problems of monitoring Clinical Pathway Typhoid Fever at ABC hospital since the staff implementing has not understood the hospital policy regarding the implementation of Clinical Pathway monitoring. Hospital policy is the legal basis for the implementation of Clinical Pathway at the hospital. ${ }^{19}$

The Clinical Pathway guide of $\mathrm{ABC}$ hospital has never been reviewed since it was set out in 2015. Some of the hospital policies on the Clinical Pathway as listed in the Clinical Pathway Guidelines require revisions because they did not conform to existing Clinical Pathway implementation standards. The reporting flow of clinical Pathway in the guidebook is outlined from the emergency department / outpatient / inpatient and submitted to the medical record, but in accordance with the literature, the Clinical Pathway was only applied to inpatients. ${ }^{4,7}$ The Clinical Pathway form filling is done by case manager (ABC Hospital: room doctor and head of the inpatient room) who has received training on Clinical Pathway. The Clinical Pathway team coordinates with other caregiver professionals involved in patient care, so that the implementation and evaluation of the Clinical Pathway is actually implemented by a multidisciplinary team. The application of Clinical Pathway is intended for predictable cases, so hospitals need to restrict the application of Clinical Pathway only to patients with a single diagnosis of Typhoid Fever without complications or complications. Clinical Pathway Guidelines need to be reviewed periodically because of medical updates and changes in hospital condition. ${ }^{11}$

The unavailability of the Clinical Pathway form in the inpatient room was an obstacle in the implementation of the Clinical Pathway. In his research, Kinsman stated that in order to monitor the implementation of Clinical Pathway in the inpatient room, duplication of the Clinical Pathway template is required as an audit card. This audit card is used 
as a representative of a Clinical Pathway within a patient's maintenance period. ${ }^{13}$

The hospital must establish Clinical Pathway documentation standard and implement them consistently. ${ }^{8}$ Documentation is performed in the inpatient room in accordance with the health services received by the patient. ${ }^{13}$ Any discrepancies are recorded in the variance column and furnished with a description / reason. To improve the compliance of Clinical Pathway form filling, the form can be incorporated as part of the patient's medical record. ${ }^{21}$

The lack of personnel / staff assigned to fill the Clinical Pathway form was one of the factors causing the cessation of Clinical Pathway form in the inpatient room including the form of Clinical Pathway Typhoid Fever. Furthermore, the case manager is a person who played an important role in the implementation of the Clinical Pathway and determined the successful implementation of Clinical Pathway. ${ }^{17,18,20}$. Case manager functions to coordinate, monitor the implementation of Clinical Pathway, conduct quality inspection of Clinical Pathway documentation, and encourage compliance of Clinical Pathway implementation. Case manager acts as an intermediary between the Clinical Pathway team and the care giver. ${ }^{20}$

The availability of human resources was one of the keys of Clinical Pathway implementation. ${ }^{22}$ Besides the human resources who were responsible for the implementation of the Clinical Pathway, the hospitals should also take into account the availability of staff who have the power to supervise the implementation of the Clinical Pathway both at the organizational and unit level. ${ }^{23}$ The hospital can designate and train senior nurses to perform the monitoring function. ${ }^{21}$

The results of interviews and questionnaires in accordance with the results of some research informed that the lack of knowledge the staff have regarding the Clinical Pathway was generally caused by poor socialization. ${ }^{20,21,24}$ The poor understading of the Clinical Pathway caused a lack of commitment to the implementation of Clinical Pathway at ABC hospital. ${ }^{25}$ The low adherence of the staff in carrying out the Clinical Pathway form filling was due to the Clinical Pathway which was considered as an additional workload for staff. $7,19,20,22$

The preparation, implementation and monitoring of the Clinical Pathway requires the role of the Medical Committee and other relevant health workers in a multidisciplinary team. ${ }^{5} \quad$ Lack of commitment, understanding of the Clinical Pathway and the lack of communication among health personnels was a constraint of implementation and monitoring Clinical Pathway. ${ }^{18}$ Building cooperation between professions is not an easy thing, especially because of the potential for conflict due to differences in professional backgroud and culture. Willingness to work in teams is necessary because of the additional workload that team members will receive in monitoring and evaluating the implementation of the Clinical Pathway. Hospitals are expected to build a system that supports inter-professional cooperation within the Clinical Pathway team. ${ }^{17}$

\section{CONCLUSION}

The implementation of Clinical Pathway Typhoid Fever monitoring at $\mathrm{ABC}$ hospital Malang has not gone well. The problem of the implementaion of monitoring of Clinical Pathway Typhoid Fever at ABC hospital Malang was due to: a) the absence of team responsible for the implementation of Clinical Pathway at ABC hospital, b) some less suitable material depicted in Clinical Pathway guide of ABC hospital, c) the absence of SPO filling Clinical Pathway form as guidance for staff implementers in the inpatient room, and d) the lack of Clinical Pathway socialization to the caregivers and related staff. From the findings above, it is suggested that to improve Clinical Pathway Typhoid Fever monitoring, ABC hospital Malang is required to immediately establish the team who is responsible for the implementation of Clinical Pathway and endorsed by the decree of the director. The team who is responsible for Clinical Pathway will further revise the Clinical Pathway Guide and prepare an SPO for the Clinical Pathway form. To improve the understanding and commitment of hospital staff to Clinical Pathway, it is necessary to regularly socialize Clinical Pathway.

\section{REFERENCES}

1. Meo MY. Pengembangan Sistem Informasi Manajemen Keperawatan Dengan Integrated Clinical Pathway Untuk Meningkatkan Kualitas Pelayanan. Jurnal Managemen Keperawatan. 2015; Vol.3 No.1 48-55.

2. Agusno M, Yoga INBH. Efektivitas Pelayanan Selama Penerapan Clinical Pathway Skizofrenia Rawat Inap Di Rsup Dr. Sardjito YOGYAKARTA. Jurnal Manajemen Pelayanan Kesehatan. 17(1). 
3. Barbieri A, Vanhaecht K, Van Herck P, Sermeus W, Faggiano F, Marchisio S, et al. Effects of Clinical Pathways In The Joint Replacement: A MetaAnalysis. BMC Medicine. 2009; 7(1):32.

4. Rotter T, Kugler J, Koch R, Gothe H, Twork S, van Oostrum JM, et al. A Systematic Review And Metaanalysis Of The Effects of Clinical Pathways On Length Of Stay, Hospital Costs And Patient Outcomes. BMC Health Services Research. 2008; $8(1): 265$.

5. Firmanda D. Clinical Pathways Kesehatan Anak. Sari Pediatri. 2006; 8(3):195-208.

6. Jones JW, McCullough LB, Richman BW. The Ethics of Clinical Pathways And Cost Control. Journal of Vascular Surgery. 2003; 37(6):1341-1342.

7. Huang Z, Lu X, Duan H, Fan W. Summarizing Clinical Pathways From Event Logs. Journal of Biomedical Informatics. 2013; 46(1):111-127.

8. Said KM, El-Sadik BRA, Mahmoud FS. Integrated Clinical Pathway Regarding Care of Children with Typhoid Fever. IOSR Journal of Nursing And Health Science 2017; 6(2).

9. De Bleser L, Depreitere R, Waele KD, Vanhaecht K, Vlayen J, Sermeus W. Defining pathways. Journal of Nursing Management. 2006; 14(7):553-563.

10. Gesme DH, Wiseman M. Strategic Use of Clinical Pathways. Journal of Oncology Practice. 2011; 7(1):54-56.

11. Cheah J. Development And Implementation of A Clinical Pathway Programme In An Acute Care General Hospital in Singapore. International Journal For Quality In Health Care. 2000; 12(5):403-412.

12. Biffl WL, Smith WR, Moore EE, Gonzalez RJ, Morgan SJ, Hennessey $\mathrm{T}$, et al. Evolution Of A Multidisciplinary Clinical Pathway For The Management Of Unstable Patients With Pelvic Fractures. Annals Of Surgery. 2001; 233(6):843.

13. Kinsman L. Clinical Pathway Compliance and Quality Improvement. Nursing Standard 2004; 18(18):33 - 35.

14. Hyett KL, Podosky M, Santamaria N, Ham JC. Valuing Variance: The Importance of Variance Analysis In Clinical Pathways Utilisation. Australian Health Review. 2007; 31(4):565-570.

15. Panella M, Marchisio S, Di Stanislao F. Reducing Clinical Variations With Clinical Pathways : Do
Pathways Work? International Journal for Quality in Health Care. 2003; 15(6):509-521.

16. Kinsman L, Rotter T, James E, Snow P, Willis J. What Is A Clinical pathway? Development of A Definition To Inform The Debate. BMC Medicine. 2010; 8(1):31.

17. Deneckere S, Euwema M, Van Herck P, Lodewijckx C, Panella M, Sermeus W, et al. Care Pathways Lead To Better Teamwork : Results Of A Systematic Review. Social Science \& Medicine. 2012; 75(2):264-268.

18. Mutiarasari D, Pinzon RT, Gunadi. Evaluasi Proses Pengembangan dan Penerapan Clinical Pathway Kasus Stroke Iskemik Akut di RS Anutapura Kota Palu. Berkala Ilmiah Kedokteran Duta Wacana. 2017; Vol.2 No.2:335-347.

19. Paat C, Kristanto E, Kalalo FP. Analisis Pelaksanaan Clinical Pathway di RSUP Prof. Dr. RD Kandou Manado. Jurnal Biomedik. 2017; 9(1):62-67.

20. Astuti YD, Dewi A, Arini M. Evaluasi Implementasi Clinical Pathway Sectio Caesarea di RSUD Panembahan Senopati Bantul. JMMR (Jurnal Medicoeticolegal dan Manajemen Rumah Sakit). 2017; 6 (2):97-111.

21. Wolff AM, Taylor SA, McCabe JF. Using Checklists And Reminders In Clinical Pathways To Improve Hospital Inpatient Care. Medical Journal of Australia. 2004; 181(8):428-431.

22. Hindle D, Yazbeck A-M. Clinical Pathways In 17 European Union Countries: A Purposive Survey. Australian Health Review. 2005; 29(1):94-104.

23. Sari I, Sundari S. Evaluasi Implementasi Clinical Pathway Krisis Hipertensi di Instalasi Rawat Inap RS PKU Muhammadiyah Bantul. Health Architecture 2017; 1(1):113-121.

24. Francke AL, Smit MC, de Veer AJ, Mistiaen P. Factors Influencing The Implementation of Clinical Guidelines For Health Care Professionals: A Systematic Meta-Review. BMC Medical Informatics And Decision Making. 2008; 8(1):38.

25. Gurses AP, Marsteller JA, Ozok AA, Xiao Y, Owens S, Pronovost PJ. Using an Interdisciplinary Approach to Identify Factors That Affect Clinicians' Compliance With Evidence-based Guidelines. Critical Care Medicine. 2010; 38:S282-S291. 